\title{
"We need to make our voices heard": Claiming space for young people's everyday environmental politics in northern Finland
}

\author{
Marika Kettunen \\ Geography Research Unit, University of Oulu, Finland, marika.kettunen@oulu.fi
}

\begin{abstract}
Recent years have seen a critical shift in young people's political participation, as young people around the world have mobilized to demand greater climate actions. Drawing on ethnographic fieldwork that consist of participant observation and 47 qualitative interviews with 15-16-year-olds residing in rural and urban areas in northern Finland, the paper contributes to rural, regional and mundane perspectives on the topic of young people's environmental politics. The paper sheds light on the myriad of ways in which young people practice environmental politics and construct their environmental citizenship and also discusses young people's political action in relation to the friction and resistance their participation stirs up in the local communities. Although promoting active citizenship is a stated goal of the Finnish education system, young people's active participation in mundane and local environmental politics is not always embraced in local communities. The paper argues for better recognition of and support for young people's everyday environmental politics and for youth participation as a way to spark wider social, cultural, and political change.
\end{abstract}

Keywords: young people, political agency, everyday politics, environmental citizenship, climate action

VERTAISARVIOITU

KOLLEGIALT GRANSKAD

PEER-REVIEWED

www.tsv.fi/tunnus

\section{Introduction}

Sanna: Well nowadays it is so, we talk about it at school and with friends, family, it is on TV, news for example.

MK: What do you talk about with your friends?

Sanna: Well mostly we talk about our carbon footprints. How we could reduce it, and how some people kind of, live over their footprints, if one could say so. What would be ecological ways of doing something. 
I engaged in a lengthy discussion with Sanna, a 15-year-old student, as she explained how she thinks that climate change affects everyone, how the changing environmental conditions cause confusion and uncertainty and make her ponder not only her daily practices but her future as well. I had this discussion in spring 2019, when I conducted ethnographic fieldwork among young people in northern Finland. The discussion reflects how contemporary youths are aware of and worried over environmental issues such as climate change, biodiversity loss, and environmental degradation (Piispa \& Myllyniemi 2019; Wahlström et al. 2019). The discussion also illuminates how environmental concerns permeate the everyday experiences and practices of contemporary young people. And the concern is warranted: the United Nations (UN 2020) states that "climate change is the defining crisis of our time" and will have severe implications for future generations. In response, recent years have witnessed a critical shift in young people's political participation and active citizenship regarding environmental issues, as youths around the globe have started to demand greater climate actions.

In the spirit of the theme of this Nordia Yearbook, this paper sets out to explore the various forms of friction that emerge from the inertia present in society and young people's political action. Approaching inertia from a political and social perspective, I explore how young people's participation and political action in the context of the current ecological crisis have raised various forms of what I call inertial friction in their local communities as they have sought to take environmental action and navigate the terrain of environmental politics. Retrospectively, the spring of 2019, when I conducted the fieldwork, represented a major turning point: global youth-led climate strikes inspired by a Swedish student - Greta Thunberg - drew students out of the schools into the streets and in front of the politicians in Finland as well. The wider landscape of the global youth climate movement but also insights like Sanna's underline how young people practice environmental politics in a myriad of ways. This aligns with a key argument of critical scholars in the fields of political geography and youth studies: although young people are often regarded as non-political due to their minor status, a variety of politics are involved (e.g. Kallio \& Häkli 2013; Skelton 2010; Wood 2012). This insight notwithstanding, little scholarly attention has been paid to the regional and everyday dimensions of young people's political action and the friction it effects in society in the wake of current ecological crises and young people's political mobilization.

Inspired by recent discussions on young people's environmental citizenship (Wood \& Kallio 2019) and political participation (Bowman 2020; Holmberg \& Alvinius 2019; Ojala 2012; Piispa \& Myllyniemi 2019), this paper offers regional, rural, and mundane perspectives on the topic of young people's everyday environmental politics, a subject that has been studied primarily in the context of political activism and climate strike movements in urban areas. Drawing on ethnographic fieldwork and qualitative interviews among 15-16-year-old youths in rural and urban northern Finland, this paper asks: how young people's environmental politics unfolds in their everyday lives and what forms of inertial friction are connected to their political participation. Everyday environmental politics is understood as consisting of both formal as well as more informal and personal political practices 
(O’Brien et al. 2008; Skelton 2010; Wood 2012) in and through which young people enact their environmental citizenship (Isin 2008). The concept of inertia provides a fruitful starting point for investigating the various forms of friction that emerge from young people's political action. It enables a better understanding of young people's participation and non-participation, which is needed in order to better recognize and foster the transformative potential that everyday youth environmental politics holds.

\section{Placing environmental politics in young people's lives}

Young people's political participation and activism in environmental, not to mention broader, issues is neither an entirely novel phenomenon nor a unique research interest. Young people have often been in the forefront of activist and environmentalist movements, expressing dissent against the state of current affairs with respect to environmental issues at global (Rome 2003) or local (Järvikoski 1995) scales. The current youth climate movement is characterized by an unequalled global scope and focus (Wahlström et al. 2019) and by young people's use of social media as a means of sharing their concerns to a global audience (Boulianne, Lalancette \& Ilkiw 2020). A justified sense of urgency is connected to their participation: if no urgent actions are taken, scientists have warned that global warming will exceed $+1.5^{\circ} \mathrm{C}$ above pre-industrial levels with severe implications for living conditions on this planet (IPCC 2018). Nonetheless, as Nissen et al. (2020: 1) point out, it is important to recognize how the current movement is "situated with and extend a legacy of activism and political engagements around the world" (see also Järvikoski 1995). Recognizing the multiplicity of young people's politics is also crucial, since the current movement "also extends from the everyday activism of young people that is not necessarily captured in standard understandings of political participation" (Nissen et al. 2020: 1).

Notions of youth political participation and active citizenship have traditionally been detached from the daily lives of young people. Critical scholars in the fields of the political geography of youth and youth studies have criticized such claims and called for more inclusive and relative understandings of young people's politics (Kallio \& Häkli 2011; Skelton 2010). By acknowledging that young people practice politics from a specific legal-political and cultural position that could be described as liminal (Wood 2012) or in-between (Skelton 2020), it has been shown how young people in fact do practice everyday politics in and through a range of practices and spaces (e.g. Bartos 2013; Harris \& Wyn 2010; Kallio \& Häkli 2013; Percy-Smith 2015) both within and beyond formal political arenas (O’Brien, Selboe \& Hayward 2018).

To demonstrate this multiplicity, researchers have distinguished capital Politics and lower case politics (e.g. Hadfield-Hill \& Christensen 2019; Skelton 2010; Wood 2012), which is also influential in terms of young people's environmental politics. The conventional notions of Politics and political participation are often defined as public, formal or institutional, and refer to public issues managed collectively through formal institutions by politicians and adults. Within this adult-centred framework (Skelton 2010), young people are marginal, although 
not totally excluded actors: taking part in planning or decision-making (Hadfield-Hill \& Christensen 2019), lobbying, organizing demonstrations, or going on a school strike (Bowman 2020) illustrate the ways in which young people can take action to influence the formal-public sphere.

Recognizing informal and private understandings of the political and lower case politics opens up a more diverse and inclusive understanding of young people's politics (Skelton 2010). For example, young people's politics can be located in the ways in which young people engage and relate with (Bartos 2013) or express their dissent towards (O’Brien, Selboe \& Hayward 2018) current environmental issues, or in the ways in which young people take up political topics or narratives (Harju 2018; Nolas, Varvantakis \& Aruldoss 2017) in their everyday life contexts. Therefore, especially with respect to young people, overlooking domestic, informal, and personal politics may render invisible the political potential and sociocultural dimensions of citizenship that lie beyond public participation and the formal-legal sphere (Harris \& Wyn 2010; Lister 2007; Wood 2012). The division of Politics/politics is used in this paper as an analytical framework that allows light to be shed on the multiplicity of young people's everyday environmental politics and inertial friction, yet maintains that these rather binary categories may 'meld and blend' (Skelton 2010) together in young people's practices.

Understanding young people's politics as something that is both public and personal, formal and informal, is productive also in terms of understanding young people's environmental citizenship. While the traditional formal-legal approaches to citizenship have approached citizenship as a legal status, Dobson (2007) characterizes environmental citizenship rather as a set of practices and acts, claiming that environmental citizenship is characterized by the public implications of citizens in their efforts to sustain or protect the environment (see also Wood \& Kallio $\left.2019^{1}\right)$. According to Dobson's view, "environmental citizenship involves the recognition that self-interested behaviour will not always protect or sustain public goods such as the environment" (Dobson 2007: 280). Linking the individual level with the common good, Dobson employs the concept of environmental citizenship to cover the private as well as the public sphere, meaning that both private and public actions have public environmental implications. Decisions made at home, such as choosing a heating system, are an example of a private decision that has public environmental implications. As Fadaee (2017) points out, these actions can be both individual and collective. Collective protests and strikes can be thought of as manifestations of collective public environmental citizenship, while coming up with an environmentally friendly dinner menu at home may be a private action made collectively by the family.

As Wolf et al. (2009) note, although environmental citizenship entails a normative account of how people should live their lives, it is practiced and challenged by people on an everyday basis. Everyday practices and negotiations can be regarded as sites in and through which young people enact their environmental citizenship (cf. Isin 2008). However, the practice of young people's environmental citizenship and their political

\footnotetext{
${ }^{1}$ In their original paper, Wood and Kallio (2019) use the term green citizenship and acknowledge that it has various expressions such as ecological, sustainable, and environmental citizenship.
} 
participation may also be challenged by the surrounding society, often by adults (Skelton 2010; Wood 2012). For example, in their study on student anti-war strikes in the early 2000s, Cunningham and Lavalette (2004) discuss how students' participation was not recognized as active citizenship but was rather interpreted as truancy by the educational institutions. Their study illuminates how young people's political participation and active citizenship become a site of struggle when young people's politics manifests in "spaces of in-betweenness which can be seen to be simultaneously sites of adult control and youthful agency" (Wood 2012: 338).

In the sphere of everyday life, personal experiences, emotions, and affects also underpin how young people enact their environmental citizenship and political agency (Fadaee 2017; Nairn 2019). Bartos (2013) claims that children's environmental engagements and relationships are influential in either discouraging or encouraging an environmental ethic, implying that personal experiences of the environment are linked to active environmental citizenship. Although ecological crises are often coupled with apocalyptic future visions and 'end of the world discourses' (see Nairn 2019), Ojala (2012) suggests that constructive hope that is not based on denial is an important motivational force for young people's pro-environmental behaviour. This also connects young people's political participation to social change and steers our attention to the transformative potential of young people's environmental politics: through their thoughts and actions, young people can decisively act as agents of broader social and political change in response to ecological crises (cf. Steinfort, Hendrikx \& Pijpers 2017).
In a time of global ecological crises, environmental citizenship is enacted through personal engagement in the everyday and local settings, yet it is inevitably connected to national, transnational, and global processes and responsibilities. Environmental citizenship should therefore be thought of as a multiscalar social practice in which the scales of environmental implications are not hierarchical but rather overlapping (Lister 2007; Dobson 2007). National educational systems in particular are regarded as effective tools in promoting environmental citizenship at multiple scales and many countries (including Finland) aim to educate their young people to be and become active and transformative environmental citizens: through political action and active participation, young people are expected to be able to address the global environmental challenges at hand (Laininen 2019; Parra et al. 2020). However, considering regional and geographical differences is important since young people's political agency and the ways in which young people construct their environmental citizenship are contextual and socially constituted, that is, they are affected by place and its affordances and limitations (e.g. Bartos 2013; Kallio \& Häkli 2013).

\section{Research material and methods}

The study draws on ethnographic fieldwork conducted between February and May 2019. That spring witnessed a major turning point in young people's political participation and active environmental citizenship as youth-led climate strikes took place all over the globe, and in Finland as well. As the climate movement has shown, young 
Table 1. Summary of research sites and interviewees in northern Finland.

\begin{tabular}{llll}
\hline Municipality & Regional features & School & Interviewees \\
\hline Urban & Regional centre & $\mathrm{U} 1$ & 13 \\
\hline Urban & Regional centre & $\mathrm{U} 2$ & 12 \\
\hline Rural & Sparsely habited & $\mathrm{R} 1$ & 11 \\
\hline Rural & Sparsely habited small town & $\mathrm{R} 2$ & 11 \\
\hline
\end{tabular}

people are individuals capable and willing to form collectives to contribute to the common good and more sustainable futures (cf. Dobson 2007). Yet regional differences in opportunities and participation exist. In Finland, climate strikes were organized throughout the country, yet mostly in bigger cities and urban centres in the capital region in southern Finland. Thus, the empirical data collected in three research municipalities in two rural and urban areas in northern Finland (Table 1.) offers regional, rural, and mundane perspectives on young people's environmental politics.

During the fieldwork, I engaged in informal conversations with local people in the research municipalities and conducted participatory observation during the youth-led school strikes and demonstrations organized in the research municipalities. I complement the data with a set of 47 interviews collected among 15-16-year-old youths (28 girls and 19 boys) in four lower secondary schools. The interview data was collected as part of a wider research project which included interviews among 15-16-year-old ninth-graders graders in urban and rural schools. The interview data therefore does not include only those young people who identified themselves as active in the youth climate movement, but enables an examination of the views and experiences of those young people who were not among the most active strikers or demonstrators.
Voluntary interviewees were recruited with the help of local teachers and the interviews were conducted as semi-structured, individual interviews during the school days. Throughout the research process, the ethical principles of the Finnish National Board on Research Integrity (TENK 2019) were followed, including the guidelines concerning underaged research participants, informed consent, and protection of participants' privacy. All names mentioned in the paper are pseudonyms.

To analyse the material, I applied the directed approach to qualitative content analysis in which previous literature on young people's everyday politics and environmental citizenship guides the initial analysis and coding the textual data (see Hsieh \& Shannon 2005). The two research questions of this study on young people's everyday environmental politics and forms of inertia connected to their participation are operationalized for data analysis in two phases. First, I paid attention to the multiplicity of young people's everyday environmental politics and examined the role of regional perspectives and rural-urban differences in young people's participation. Second, I identified and analysed the different forms of inertial friction connected to young people's political participation and non-participation. 


\section{Young people's environmental politics and citizenship in northern Finland}

\section{Multiple and contested everyday environmental politics}

In Finland, the first bigger youth-led climate strikes were organized in March 2019, when students and young people in over 20 cities throughout the country organized strikes as part of the global youth climate movement (also Albrecht et al. 2020). Young people's political mobilization was widely discussed in the schools and social media as the events and actions unfolded when I was conducting the fieldwork. Strike actions and other, more public and formal, forms of environmental Politics were not mentioned by the interviewees in February, whereas after the strikes in March the interviewed young people both in urban and rural areas began to address strikes and demonstrations as a means of youth political participation. This was irrespective of whether a strike has been organized in their municipality or not. Strikes represented a means of environmental Politics for young people who wanted to have an influence on institutional politics and the wider political atmosphere and policymaking:

"We are too young to like vote in parliamentary elections, and can't do that much, but we younger people do have the climate strikes and such. At least that way we can influence things.” Martta (R2)

For some youths, the climate strikes provided a meaningful way of practicing active citizenship through taking part in environmental Politics on their own terms.
The strike action seemed to provide an example of youth political participation also for those youths who did not take part in the strikes themselves. Instead, youths like Martta challenged the position that was offered by adults by taking a political stand in the discussion and supporting the strikes (cf. Harju 2018). Similarly Vilja, interviewee in the rural municipality, questioned the dominant discourse in Finland that holds that young people are reluctant to participate in politics, and emphasized strikes as a means to practice active environmental citizenship:

"There has been a lot of talk about how young people are not interested in politics and so on. The strikes have shown something at least, that we young people too want to have a say in this... After all, it's our future we're talking about. It's about us - we need to make our voices heard." Vilja (R2)

Young people's active public participation was, however, contested by the adults. This aligns with notions how young people's participation is not always embraced in the adult-centred framework of Politics (e.g. Skelton 2010; Wood 2012). Although strikes represented a meaningful way of political participation for some youths, in many schools the school staff had denied the young people from taking part in the strike and interpreted it as truancy. In one of the rural schools, the members of the student council had asked the school staff whether they could organize a collective act in order to show their support for the global climate strike movement. On the young people's own initiative, the student council was then allowed to organize a climate march at the end of the school day one day prior to the global school strikes. Although the students 
in the rural school were given the chance to organize and take part in a climate protest, it happened in the more narrow frames set by the school, underlining the adult-centeredness of young people's participation in school settings (Wood 2012).

Many of the interviewed youths who took part in such environmental Politics also explained that their political agency simultaneously unfolded through more mundane and private practices of politics beyond the formal sphere, blending environmental Politics and politics (Skelton 2010). However, there were also those who did not want to take part in environmental Politics and preferred private and informal practices:

"Umm, participating in politics, getting into marches and such, I'm not interested in that. But at home, saving energy and water, turning off the lights, that I'm totally okay with. Recycling and all such things. In a way, it is really great that youths can revolt against something that they don't like. But then again, I see young people out there littering and leaving candy wrappers in the streets and so on, you can't deny it. So in some ways I think the demonstrations are good, but on another level some of them should also look in the mirror." Antton (U2)

Antton's comment opens up a more diverse understanding of young people's personal and mundane environmental politics. Like Antton, many interviewed youths found more suitable spaces for practicing environmental politics in informal and domestic settings. Similarly, many interviewees described how they practice political agency through private and informal practices such clothes purchases and the consumption of other goods and services, recycling, household energy use, and diet. For the interviewed young people, many consumerist practices appeared as important arenas for practicing everyday environmental politics and constructing their environmental citizenship.

Young people can also practice everyday politics by taking up issues that are important to them (Kallio \& Häkli 2011; Harju 2018). As Nolas et al. (2017) propose, the act of 'talking politics' can be regarded as an important aspect of young people's everyday politics. Many interviewed youths brought up how they talk about environmental issues at home with their family members and how it blended with other practices of everyday politics:

"We have talked about it [climate change] a lot with my parents and we try to do things at home. For example, I don't buy as many clothes as before and such. And I try to influence my family members' consuming as well. And it has even worked." Anna (R2)

Besides homes, schools formed important arenas for talking environmental politics. Some interviewees told they had done group assignments related to environmental issues and talking environmental politics after such assignments continued later on. As Sanna's comment about comparing carbon footprints in the very beginning of this paper illustrates, young people talk about environmental issues at school and share knowledge and news they have seen on social media, for example. The school therefore appeared as an important social and political arena where young people can practice mundane environmental politics among peers (cf. Wood 2012).

Young people's environmental action was also entwined in emotions concerning current environmental issues. More importantly, the understanding that one's 
mundane actions have an impact seemed to provide hope for those youths who envisioned their futures amidst ecological crises:

"When I was younger, 12 or 13 years old, I remember that I was like 'oh no, climate change is coming, and everything is going to end up badly. But now that I am a bit older, I have understood that I can't just stand crying on the side-lines and do nothing. I too should do something to stop it." Oona (R1)

Many youths in the study articulated how doing something tangible and practicing multiple everyday politics eased the anxiety that they experienced due to environmental issues and the related threats. Oona's case also illustrates, how not only positive but also negative emotions can mobilize as environmental politics that foster young people's emotional well-being.

\section{Regional perspectives and rural-urban differences}

Young people brought up in the interviews how the urban and the rural provided different settings for practicing environmental citizenship and everyday politics. Whereas large strikes and demonstrations were not organized in the rural municipalities, more organized strikes and demonstrations were organized in the urban municipality as part of the global school strike movement. Although young people in one of the rural schools organized a climate march during the spring, young people described strikes and demonstrations as predominantly urban modes of youth political participation:

'I don't think there have been any real strikes or marches in our town. But we have been talking about what's happening elsewhere in the world and in southern Finland." Anja (R2)

Young people's actual possibilities to take part in the strikes in rural regions and smaller towns were more limited. Anja's comment, however, also illustrates how social media and the Internet played a large part in allowing young people to connect to other youths and gain information about the global strikes around the globe and bigger cities in Finland as well. Social media provided an important site for environmental socialization that was not bound with young people's place of residence: most of the interviewed youths told how they had heard of the climate movement in the news or actively looked for information on the Internet or social media platforms (cf. Wahlström et al. 2019).

And yet, there seemed to be a sharp contrast in the cultural atmosphere between the urban and the rural schools in this study. For example, while talking with Minna in the urban school she emphasized how easily daily and personal changes can be made. She said that was easy for her and her classmates to eat less meat because there are vegetarian options at school. In the smaller rural research sites, the school usually offered a vegetarian option too, but the cultural atmosphere was not as tolerant as in the urban schools. Salli in the rural school said that she used to be a vegetarian, but that her classmates had teased her about it. Also other interviewees in the same municipality brought up how climate change was a contentious topic in the classroom. Some youths even said that they tried to avoid the topic because it often caused quarrels in the classroom. The case highlights how young people's insights 
about climate change and their personal environmental engagements can become a site of struggle that the students and their teachers quarrel over:

\section{"I bring the matter up [climate change] in class, but especially the boys are like ... well, there's no point talking with them. I don't really have, well I have this one friend in upper secondary school. We are good friends and share the same values. I talk with her a lot." Salli (R2)}

The act of talking politics with friends and classmates appeared important in constructing and contesting environmental engagements and environmental citizenship. Salli and some of her classmates also pointed out that it was not always possible to make environmentally friendly choices even though they wanted to; for instance, they claimed that recycling plastics was not possible in their hometown. Although recycling is a rather established practice in many Finnish households and especially in bigger cities, in smaller municipalities the lack of recycling centres, for example, may limit young people's lifestyle choices. Local responses and the lack of infrastructure, therefore, may turn young people's mundane acts and practices like dietary choices and recycling into interesting sites of conflictual everyday environmental politics.

In rural regions and smaller municipalities with fewer young people, there might be less like-minded peers with similar interests. Salli also emphasized the importance of having that one like-minded friend with whom she could share her thoughts on environmental issues and climate change. When I asked whether they had been talking about the climate strikes at school, Salli said that they had been discussing Greta
Thunberg in civics class. In her opinion, it was not enough:

"No. Only in civics class. We talked about that Swedish girl who kind of started the whole thing. But here, people don't care. Not at all." Salli (R2)

Salli's comment illustrates well how some of the interviewed young people, especially in the rural municipalities, articulated how they felt that the local people and culture did not support their environmental engagement or share their values. The young people emphasized their frustration arising from the experienced difficulties in claiming their spaces of participation and having their voices heard in the local communities. Some interviewed young people also highlighted the role of schools and the need for constructive discussion about the topic. Although fostering active environmental citizenship has long been a guiding principle in Finnish environmental education (Laininen 2019), local schools and individual teachers have a great freedom in the implementation of the curriculum in the local level and thus regional differences may exist in schooling as well.

\section{Inertial friction in young people's environmental politics}

The analysis illustrates how young people's agency comes into contact with various sociocultural and institutional barriers: the ways in which young people practice active environmental citizenship and reason their political action in their local communities were often entangled with various forms of inertial friction. When analysing further these 
frictions, four partly overlapping dimensions were identified: namely scalar, intergenerational, intragenerational, and gendered.

When reasoning their political participation, and more importantly their non-participation, the interviewed youths evidenced multiple and overlapping scalar constructions ranging from global and transnational to national and local responsibilities. The everyday and local scale, however, offered an important site for young people's environmental politics, and many interviewed youths brought up how they think that individual acts at the local level are an important means to practice environmental politics. Yet, many interviewed youths like Veera acknowledged the importance of individual and local solutions but criticized the emphasis on consumer choices at the expense of the wider structures and systems producing environmental degradation:

\section{"What difference would it make if I tell some} big company that they should shut down their oil rigs. While they're doing that, we consumers here are bickering with each other if someone uses paper towel or orders something from China, stickers or something [laughing]. There's way too much talk about consumer choices." Veera (U1)

Veera argued that the emphasis is placed too much on individual consumers, who are pressured to make the right choices, thus criticizing the individualized expectations connected to environmental citizenship. While the young people referred to the scalar dimensions with respect to their mundane participation or non-participation, the intergenerational dimensions of inertia manifested most visibly in the relationship between the older generations and young people's active participation in the climate strikes (also Holmberg \& Alvinius 2019). Whereas in some schools, especially at the upper secondary level, teachers encouraged their students to take part in the climate strikes and emphasized it as a means to exercise active citizenship and civic skills, many elementary and lower secondary schools strictly forbid the young people from participating in the climate strikes. The friction between the strikers, their parents, and the educational institutions was clear in the interviews as well:

"The whole idea of the strike was that adults just do not get it. The idea was to do just the opposite of what they say, to not come to school, that's the real demonstration. It doesn't work. if you strike after school. Some teachers said that, well, you should just go after school. But that would have been the whole reason for going there, to make our teachers understand. But they just did not get it." Lilja (U2)

As Lilja's teachers' advice to go to the demonstration only after school suggests, young people's active agency was interpreted as truancy rather than the act of civil disobedience that it represented for the young people themselves (cf. Cunningham \& Lavalette 2004). Lilja described an intergenerational conflict that arose when her parents and teachers had denied her participation. She stated that it was ironic how the idea behind the climate strike itself was that adults do not understand the climatic emergency and were not taking sufficient action in order to mitigate its impacts. Adults thus ended up denying her participation, which illuminates how young people's political agency in the context of climate strikes often remained underappreciated. For Olivia and the others who took 
part in the strike, practicing environmental politics and having a chance to influence formal political decision-making was more important than being given recognition for their political agency:

\section{"I think it's so stupid that just when young people have the potential to influence things it is denied from us. But I didn't come to school that day, I'll have to catch up on the missed work, because I went to the city centre. And as I understood, most everybody went to school. I think it's stupid when we had a real opportunity to have a say. It's not that big of a deal if you have to make up for some missed classes." Olivia (U2)}

Although some interviewed youths admitted that they or their classmates might have used the strike as an excuse to skip school, many interviewed youths also articulated the feelings of injustice that arose when their participation was denied. These struggles highlight the role of educational institutions and teachers in arbitrating the inertial friction between young people's political agency and the society.

While some interviewed youths brought to the fore young people's active citizenship and stated that young people should take the initiative, other interviewed young people referred to intergenerational inertia from a different perspective. They in fact emphasized their minor status and situated themselves as not yet politically active with no or only little possibilities to make a difference or have a say, emphasising the responsibility of older generations and adults:

"They [the students who were on strike] can't do anything yet, but when they grow up and start working, then they can actually make

\section{things better. And if they become politicians, it's possible to enact laws." Verner (R2)}

Verner's comment illustrates how he thinks that young people will have more possibilities to act when they are adults and 'proper citizens' entering working life and formal political arenas. Verner made a clear distinction between himself and those who take part in environmental politics: by talking about 'them' instead of 'us' he detached himself from the young people that took part in the school strikes and those who more actively talked about environmental politics in school, for example. He also admitted that the only reason for him to take part in the strike would have been the possibility of skipping class. "Climate change is a bad thing, but what can I do", he concluded.

These critical insights from Verner also illuminate how the global climate movement has brought to the fore young people's environmental concerns and critiques. Yet, even in the same region or local community there is no homogeneous group of young people working towards shared aims: in addition to the intergenerational dimensions, inertial friction exists within groups of young people as well. Acts and practices that might seemingly appear as non-participation and political disengagement are also an important aspect of young people's everyday environmental politics. By opposing and sometimes openly criticizing those who practice more active environmental citizenship, these youths also practice everyday politics, reproduce intergenerational inertia, and claim their own anti-environmental citizenship.

Verner's insights above, Salli's note on classmates teasing her, and Minna's point about dietary choices earlier in this paper 
all reflect a wider gendered dimension that is connected to intragenerational inertia and young people's political participation. The findings of this study illustrate that girls were more active in overtly practicing everyday environmental politics than boys, who more often articulated their non-participation and emphasized disregard. This aligns with Wahlström et al. (2019) findings about the predominance of female participants in the youth climate movement in Europe. They suggest that "the movement's female leaders may have a strong mobilizing effect on (particularly young) women" (Wahlström et al. 2019: 5). Also in this study, many interviewees both in urban and rural contexts referred to Greta Thunberg, who seemed to represent a figure of youth empowerment and even a role model, especially for girls.

\section{Recognizing transformative potential: from minors to political actors}

Young people's political participation may appear as something that is not expected, or sometimes not even wanted, by the local community. Within the inertial frictions related to young people's political participation, however, lies the transformative potential of young people's everyday environmental politics. Young people can provoke cultural and political change through both collective mobilization and individual acts. The research material suggests that as the school strikes and demonstrations became more common and visible, young people began to consider them as a meaningful and effective means of practicing Politics. In practice, the collective mobilization targeted the political leadership, whose actions the young people perceived as insufficient (cf. Holmberg \& Alvinius 2018), yet it also raised awareness among peers, teachers, and parents. Likewise, individual acts proved to be transformative as well, as demonstrated by Anna's insights about how the act of talking politics had concrete transformative power in her family, who had changed their consumption habits based on the discussions.

Often 'in-between' spaces such as schools, where young people practice their political agency and yet are still more or less controlled by adults (Wood 2012), appeared as contentious sites with respect to young people's political participation and transformative potential. The paper illustrates how many youths were denied the opportunity to take part in the school strikes even though for young people it represented an important arena for practicing environmental Politics and driving political change. In the school setting, adults' and young people's own perceptions of what kind of environmental citizenship young people should pursue was often inconsistent with the active citizenship that some pro-environmental youth enacted through informal environmental politics. Conflicts were not only intergenerational but also intragenerational: personal choices such as diet could be an important assertion of environmental political agency. Thus, it is not only the formal education and its content but also teachers and peers that prove influential in how young people's transformative potential and active citizenship develops.

While these observations are intertwined with the notion of young people's role as capable political actors here and now (Skelton 2010), young people's environmental citizenship entails important future-oriented aspects. Some interviewed 
youths underscored their potential as future change-makers, highlighting their future transformative potential by assessing that their chances to change things would be bigger when they were adults in work life. On the other hand, some interviewees stressed their liminal formal-legal status as underage youths with limited possibilities to take action (cf. Wood 2012). Young people like Verner, for example, emphasized the role of political leaders and adults as the people who can and should take action because young people cannot take part in formal and institutional Politics.

Realizing the transformative potential of one's political action may also help to ease worry and anxiety connected to degrading ecological conditions. While some interviewed youths found more formal and public actions like strikes a way of meaningful participation, many youths also brought to the fore the importance of everyday and private acts and practices from the perspective of their emotional wellbeing. Although these political actions may also cause friction, and sometimes even conflict, at the local level and in local communities, practicing everyday environmental politics can contribute to creating more hopeful images that ease anxiety related to environmental issues (see also Ojala 2012; Pihkala 2017).

\section{Conclusions}

Young people can practice environmental politics in multiple ways, and youth political participation can create sites of struggle that contest the prevailing power relations of the current state of environmental politics and related sociocultural practices. By examining the lives and experiences of young people in three municipalities in rural and urban northern Finland, the paper provides a more nuanced understanding of young people's environmental politics and (non-)participation in relation to their agency and position in the local communities and adult society. The concept of inertia allows a novel way of interrogating the political potential in young people's lives and contributes to better understanding how young people experience, reproduce, and seek to challenge the current state of environmental degradation through their everyday politics. By better recognizing the multiplicity of young people's environmental politics and the barriers to their political agency, it is possible to foster more inclusive and transformative understandings of young people' politics and environmental citizenship.

The global youth climate movement has mobilized young people to take action on environmental issues and has given rise to various forms of youth environmental Politics. However, it is good to bear in mind that there are multiple and divergent voices among the young people as well, and this paper highlights those youths who often stay in the shadow of more active environmentalists and protestors. Through their experiences, the paper also brings to the fore how the local, mundane, and informal sites are important for young people's environmental politics and citizenship formation (cf. Wood \& Kallio 2019). Regional differences exist as well: the paper illustrates how young people in the rural research municipalities in particular experienced difficulties in claiming their spaces of participation and practicing active environmental citizenship. As young people's insights concerning the lack of recycling possibilities and struggles regarding a vegetarian diet illustrate, contradictions between 
local possibilities, cultural atmosphere and attitudes, and young people's everyday environmental politics emerged.

Although young people find ways to practice everyday environmental politics on their own terms, their political participation is not always recognized in the local communities. Paradoxically, young people are educated to be active environmental citizens (Parra et al. 2020) but the ways in which they take up political issues or practice their citizenship are not always accepted or supported in the local communities. Especially the school strikes demonstrate how young people's political participation can be misrecognized by adults and schools as mere truancy (also Cunnighman \& Lavalette 2004) - which it in fact was for some youths, while for others it was a meaningful way to take political action and practice active citizenship. Recognizing the value of young people's diverse participation is nevertheless important since previous research has demonstrated that experienced injustices and the lack of meaningful opportunities might result in political disengagement or withdrawal from democratic participation (e.g. Manning \& Holmes 2013; Pontes, Henn \& Griffiths 2019). The fieldwork in the present paper was conducted during a limited timeframe and further research on the possible legacies of young people's everyday environmental politics would be needed (Nissen et al. 2020) to investigate the long-term effects of the young people's mobilization and potentially experienced injustices.

Besides intergenerational conflicts, the young people's political participation entailed gendered dimensions as well. Considering previous studies indicating that in Finland girls experience more uncertainty related to climate change than boys (Piispa
\& Myllyniemi 2019) and similar findings in this study, the findings suggest that girls' affective responses have a tendency to mobilize as environmental politics. Boys as well do practice active environmental citizenship, yet the ways in which the boys in this study enacted environmental politics more often reproduced intergenerational inertia. Given the importance of local setting and cultural atmosphere in the construction of young people's environmental citizenship, future research might further explore the relationship between non-participation and its gendered aspects in specific geographical settings.

The paper has shown how young people can be political actors in their everyday lives and spark wider cultural and political change through their individual and collective actions. Although tackling the ecological crises requires structural and institutional changes and individual responsibilities should not be overemphasized, local cultural and political transformation is needed as well. There is a clear need for better recognition of the various aspects of young people's everyday environmental politics and its transformative potential. Young people should be supported and encouraged in their efforts to engage in the various practices and processes of social, political, and ecological transitions needed to respond to the ecological crises. Given the relationship between affective entanglements and young people's everyday environmental politics highlighted in this paper, recognizing and supporting young people's agency and participation in contexts that they hold important is beneficial also in terms of fostering active citizenship in the sphere of the everyday life and dealing with the increasing anxiety related to environmental issues (Nairn 2019; Pihkala 2017). 


\section{Acknowledgements}

I am grateful to the young people who took part in this study. I would also like to thank the editors and two anonymous reviewers for their insightful comments and suggestions.

\section{References}

Albrecht, E., N. Tokola, E. Leppäkoski, J. Sinkkonen, I. Mustalahti, O. Ratamäki \& J. Viljanen (2020). Nuorten huoli ja ympäristökansalaisuuden muotoutuminen. In Pekkarinen, E. \& T. Tuukkanen (eds.): Maapallon tulevaisuus ja lapsen oikeudet, 99-110. Lapsiasiavaltuutetun toimiston julkaisuja 2020:4.

Bartos, A. E. (2013). Friendship and environmental politics in childhood. Space and Polity 17: 1, 17-32. doi:10.1080/13562576.2013.780711

Boulianne, S., M. Lalancette \& D. Ilkiw (2020). "School Strike 4 Climate": Social media and the international youth protest on climate change. Media and Communication 8: 2, 208-218. doi:10.17645/mac.v8i2.2768

Bowman, B. (2020). 'They don't quite understand the importance of what we're doing today': the young people's climate strikes as subaltern activism. Sustainable Earth 3: 16. doi:10.1186/ s42055-020-00038-x

Cunningham, S. \& Lavalette, M. (2004). 'Active Citizens' or 'Irresponsible Truants'? School Student Strikes against the War. Critical Social Policy 24: 2, 255-269. doi:10.1177/0261018304042002.

Dobson, A. (2007). Environmental citizenship: Towards sustainable development. Sustainable Development 15, 276-285.

Fadaee, S. (2017) Environmentally friendly food initiatives in Iran: between environmental citizenship and pluralizing the public sphere. Citizenship Studies 21: 3, 344-358, doi:10.1080/13621025 .2016.1277979

Hadfield-Hill, S. \& P. Christensen (2019). 'I'm big, you're small. I'm right, you're wrong': the multiple $\mathrm{P} /$ politics of 'being young' in new Sustainable Communities, Social \& Cultural Geography doi $: 10.1080 / 14649365.2019 .1645198$

Harju, A. (2018). Children practising politics through spatial narratives. Children's Geographies 16: 2, 196-207. doi:10.1080/14733285.2017.1350635

Harris, A., \& J. Wyn (2010). Special issue of YOUNG on 'Emerging forms of youth participation: Every- day and local perspectives'. Young 18: 1, 3-7.

Hsieh, H.-F. \& S. E. Shannon (2005). Three Approaches to Qualitative Content Analysis. Qualitative Health Research 15: 9, 1277-1288. doi:10.1177/1049732305276687.

Holmberg, A. \& A. Alvinius (2019). Children's protest in relation to the climate emergency: a qualitative study on a new form of resistance promoting political and social change. Childhood 27: 1, 78-92. doi:10.1177/0907568219879970

IPCC (2018). Global Warming of $1.5^{\circ} \mathrm{C}$ : Summary for Policy Makers. Intergovernmental Panel on Climate Change.

Isin, E. (2008). Theorising Acts of Citizenship. In Isin, E. \& G. M. Nielsen (eds.): Acts of Citizenship, 15-43. Palgrave Macmillan.

Järvikoski, T. (1995) Young people as actors in the environmental movement. YOUNG 3: 3, 80-93. doi: $10.1177 / 110330889500300306$.

Kallio, K. P. \& J. Häkli. (2011). Are There Politics in Childhood? Space and Polity 15: 1, 21-34.

Kallio, K. P. \& J. Häkli (2013). Children and young people's politics in everyday life. Space and Polity 17: 1, 1-16. doi:10.1080/13562576.201 3.780710.

Laininen, E. (2019). Transformatiivinen oppiminen ekososiaalisen sivistymisen mahdollistajana. Ammattikasvatuksen Aikakauskirja 20: 5, 16-38.

Lister, R. (2007). Inclusive citizenship: Realizing the potential. Citizenship Studies 11: 1, 49-61, doi:10.1080/13621020601099856

Manning, N. \& M. Holmes (2013). He's snooty 'im': exploring 'white working class' political disengagement. Citizenship Studies 17: 3-4, 479-490, doi:10.1080/13621025.2013.793082

Myllyniemi, S. \& T. Kiilakoski (2019) Tilasto-osio. In Pekkarinen, E. \& S. Myllyniemi (eds.): Vaikutusvaltaa Euroopan laidalla. Nuorisobarometri 2018. Nuorisotutkimusverkosto/Nuorisotutkimusseura, 11-108. Opetus- ja kulttuuriministeriö \& Valtion nuorisoneuvosto \& Nuorisotutkimusseura, Helsinki.

Nairn, K. (2019). Learning from Young People Engaged in Climate Activism: The Potential of Collectivizing Despair and Hope. YOUNG 27: 5 , 435-450. doi:10.1177/1103308818817603

Nissen, S., J. H.K. Wong \& S. Carlton (2020). Children and young people's climate crisis activism a perspective on long-term effects. Children's Geographies. doi: 10.1080/14733285.2020.1812535

Nolas, S.-M., C. Varvantakis \& V. Aruldoss (2017). Talking politics in everyday family lives. Contemporary Social Science: Journal of the Academy of Social Sciences 12: 1-2, 68-83.

O‘Brien, K., E. Selboe \& B. M. Hayward (2018). Exploring youth activism on climate change: dutiful, 
disruptive, and dangerous dissent. Ecology and Society 23: 3. doi:10.5751/ES-10287-230342

Ojala, M. (2012). Hope and climate change: the importance of hope for environmental engagement among young people. Environmental Education Research 18: 5, 625-642, doi:10.1080/1350462 2.2011.637157

Parra, G. et al. (2020). Education for Environmental Citizenship and Education for Sustainability. In Hadjichambis A. et al. (eds.): Conceptualizing Environmental Citizenship for 21st Century Education. Environmental Discourses in Science Education vol 4, 149-160. Springer. doi:10.1007/978-3-030-20249-1

Percy-Smith, B. (2015) Negotiating active citizenship: young people's participation in everyday spaces. In Kallio, K. P. \& S. Mills (eds.): Politics, Citizenship and Rights, 401-422. Springer Reference, Heidelberg.

Pihkala, P. (2017). Päin helvettiä? Ilmastoahdistus ja toivo. Kirjapaja, Helsinki.

Piispa, M. \& S. Myllyniemi (2019). Nuoret ja ilmastonmuutos. Tiedot, huoli ja toiminta Nuorisobarometrin valossa. Yhteiskuntapolitiikka 84: 1, 61-69.

Pontes, A. I., M. Henn \& M. D. Griffiths (2019). Youth political (dis)engagement and the need for citizenship education: Encouraging young people's civic and political participation through the curriculum. Education, Citizenship and Social Justice 14: 1, 3-21. doi:10.1177/1746197917734542

Rome, A. (2003). "Give Earth a Chance": The Environmental Movement and the Sixties. The Journal of American History 90: 2, 525-554.

Skelton, T. (2010). Taking young people as political actors seriously. Area 42: 2, 145-151.

Steinfort, L., B. Hendrikx \& R. Pijpers (2017). Communal performativity - A seed for change? The solidarity of Thessaloniki's social movements in the diverse fights against neoliberalism. Antipode 49: 5, 1446-1463. doi:10.1111/anti.12351.

TENK. (2019). The ethical principles of researching human participants and ethical review in the human sciences in Finland. The Finnish National Board on Research Integrity TENK guidelines 2019. Publications of the Finnish National Board on Research Integrity TENK 3/2019.

UN (2020). United Nations. The Climate crisis - a race we can win. <https://www.un.org/sites/un2. un.org/files/un75_climate_crisis.pdf> (Accessed 3 Aug 2020).

Wahlström, M., P. Kocyba, M. De Vydt \& J. de Moor (2019). Protest for a Future: Composition, Mobilization and Motives of the Participants in Fridays For Future Climate Protests on 15 March, 2019 in 13 European Cities. Keele University e-Prints, Keele, UK.
Wolf, J., K. Brown \& D. Conway (2009). Ecological citizenship and climate change: Perceptions and practice. Environmental Politics 18: 4, 503-521.

Wood, B. E. (2012). Crafted within liminal spaces: Young people's everyday politics. Political Geography 31: 6, 337-346. doi:10.1016/j.polgeo.2012.05.003.

Wood, B. E. \& K.P. Kallio (2019). Green citizenship: Towards spatial and lived perspectives. In Davoudi, S., H. Blanco, R. Cowell \& I. White (eds.): Routledge Companion to Environmental Planning and Sustainability, 171-180. Routledge, London. 